\title{
Would you buy this car without a warranty?
}

\author{
Charles B. Huddleston, MD, and Jose Greenspon, MD
}

\author{
From the Department of Surgery, Saint Louis University School of Medicine, St Louis, Mo. \\ Disclosures: Authors have nothing to disclose with regard to commercial support. \\ Received for publication May 25, 2016; accepted for publication May 26, 2016; available ahead of print June 18, \\ 2016. \\ Address for reprints: Charles B. Huddleston, MD, 1465 S Grand Blvd, St Louis, MO 63104 (E-mail: chuddle7@ \\ slu.edu). \\ J Thorac Cardiovasc Surg 2016;152:927-8 \\ $0022-5223 / \$ 36.00$ \\ Copyright (C 2016 by The American Association for Thoracic Surgery \\ http://dx.doi.org/10.1016/j.jtcvs.2016.05.052
}

We see that shiny new sports car in the dealer showroom and imagine driving off in it when someone (usually a spouse) jolts us back to reality with questions regarding safety, reliability, need for service, and overall performance. Like a new sports car, there is perhaps nothing more interesting to a surgeon than learning about a new technique to treat a difficult problem, such as congenital diaphragmatic hernias (CDHs). What we need to know before changing to this new technique is its safety, reliability, need for service (dealing with complications), and overall performance. In this issue of the Journal, Arnaud and co-authors ${ }^{1}$ describe the use of the transversus abdominis muscle as a rotational flap to close large CDHs or diaphragmatic agenesis. This article adds to the growing literature regarding the use of autologous tissue as an option in these challenging cases. Autologous tissue may have a lower recurrence rate than a prosthetic patch according to some reports in the literature, although a more recent study found that prosthetic and primary repairs carry recurrence rates that are more similar than previously described. ${ }^{2}$

Autologous tissue as a flap repair for $\mathrm{CDH}$ is not a new concept. As early as 1962, Meeker and Snyder ${ }^{3}$ described using the anterior abdominal musculature as a repair option, and this was followed by a study in 2010 in which Nasr and colleagues ${ }^{4}$ reported similar recurrence rates using this type of flap to prosthetic repairs. Moreover, in 1983, Bianchi and colleagues ${ }^{5}$ described the use of reversed latissimus dorsi muscle flap in the context of diaphragmatic agenesis or large diaphragmatic defects, and subsequent to this there have been multiple articles describing different autologous muscle flaps. ${ }^{6-8}$ The split abdominal muscle flap technique that Scaife and colleagues ${ }^{8}$ describe involves the dissection of the internal oblique and transversus muscles from the external oblique, and this composite is used to close the defect. Arnaud and colleagues ${ }^{1}$ describe a technique where only the transversus abdominis muscle is dissected away from the abdominal wall and rotated as a patch alone. Of the 16 patients who underwent the procedure over what the authors report to be a 20 -year period, 12

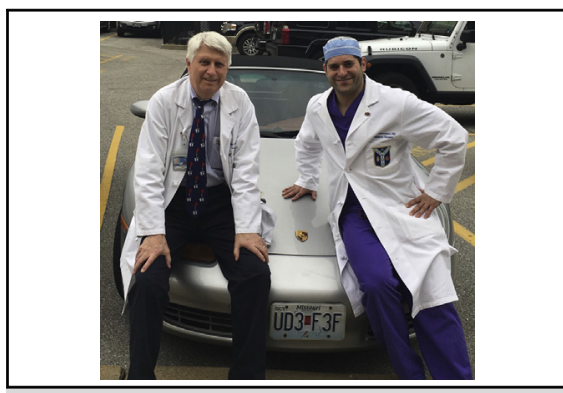

Drs Greenspon and Huddleston with Dr Greenspon's shiny sports car.

Central Message

To gain wide acceptance, any new surgical technique must demonstrate safety, efficacy, reproducibility, reliability, and durability.

See Article page 925.

survived. What is unclear from this article in comparison with many other articles that describe a technique of this nature is the length of time these patients were followed, the recurrence rate, and the other postoperative complications among the survivors. Although this article was not meant to be a retrospective review of institutional data regarding the use of this technique, the importance of recurrence rates and complications is of paramount importance when considering whether one should adopt a new technique. In addition, the authors of this article describe an experience that spans approximately 2 decades. That time span would allow for the authors to report on whether these patients are at an increased risk of complications, such as abdominal wall hernias, chest wall deformities, and scoliosis.

This technique article describes yet another option in the management of large CDHs or diaphragmatic agenesis. This approach may be advantageous in that it uses only the innermost muscular layer; however, the risk of recurrence and other complications will need to be determined as this approach is adopted. Let's see the performance record before we drive off.

\section{References}

1. Arnaud AP, Martin A, Habonimana E, Frémond B. Single transversus abdominis muscle flap: Another possibility for large congenital diaphragmatic hernia repair. J Thorac Cardiovasc Surg. 2016;152:925-6.

2. Tsai J, Sulkowski J, Adzick NS, Hedrick HL, Flake AW. Patch repair for congenital diaphragmatic hernia: is it really a problem? J Pediatr Surg. 2012; 47:637-41. 
3. Meeker IA, Snyder WH. Surgical management of diaphragmatic defects in the newborn infant. A report of twenty infants each less than one week old (1956-1961). Am J Surg. 1962;104:196-203.

4. Nasr A, Struijs MC, Ein SH, Langer JC, Chiu PP. Outcomes after muscle flap vs prosthetic patch repair for large congenital diaphragmatic hernias. J Pediatr Surg. 2010;45:151-4.

5. Bianchi A, Doig CM, Cohen SJ. The reverse latissimus dorsi flap for congenital diaphragmatic hernia repair. J Pediatr Surg. 1983;18: 560-3.
6. Sydorak RM, Hoffman W, Lee H, Yingling CD, Longaker M, Chang J, et al Reversed latissimus dorsi muscle flap for repair of recurrent congenital diaphragmatic hernia. J Pediatr Surg. 2003;38:296-300.

7. Okazaki T, Hasegawa S, Urushihara N, Fukumoto K, Ogura K, Minato S, et al. Toldt's fascia flap: a new technique for repairing large diaphragmatic hernias. Pediatr Surg Int. 2005;21:64-7.

8. Scaife ER, Johnson DG, Meyers RL, Johnson SM, Matlak ME. The split abdominal wall muscle flap — a simple, mesh-free approach to repair large diaphragmatic hernia. J Pediatr Surg. 2003;38:1748-51. 